\title{
Doing Fatherhood in the Middle Nile. Fatherhood, Masculinity and Change in Rural Northern Sudan
}

\begin{abstract}
The paper represents an effort to understand what it means to be a father in modern rural Northern Sudan. After a brief consideration of a local model of manhood and various forms of fatherhood in the Sudanese societies, its rich cultural context is examined in some detail. It is evident that fatherhood is intricately related to a wide variety of practices, customs and narrations, all of which can throw some light on the local model of masculinity and its dynamics. The paper suggests that in case of Muslim communities of Northern Sudan fatherhood is, first of all, a father-son relation which is aimed to prepare a boy to the role of "a very important man." Just so little and so much. Since quite often a young generation is not willing or not able to fulfil the fathers' expectations, it is neither a simple or obvious matter. The issue is also to explore the discourses and the practices of "globalized fatherhood"- for example, how new communication technologies are used to cultivate the fatherchildren relations. Though the paper refers to certain ethnographic experiences in Northern Sudan, it is not a result of systematic research on fatherhood. It can be rather called a "personal ethnology" - it comes from author's ethnographic observations (field research in 2010 and 2013) as well as from the fact being a father himself.
\end{abstract}

Keywords: fatherhood, masculinity, Sudan, ethnographic research

Meyer Fortes (1950) pointed out a long time ago that parenthood was the foundation of a family structure in Africa. Nothing indicates that this situation has radically changed. Parenthood nowadays, as in the times of Meyer Fortes, is a sine qua non on the way to maturity and independence of human being (Barclay 1964: 137; Nsamenang 1987: 388-413; Smith 2016, 2017). However, before the "global village" era, each African culture perceived this institution differently. Family relations resulted from the social systems, religious beliefs or economics. In relation 
to those factors the rights to children, the place of residence of the spouses, or the relationship between them were established. Unfortunately, we do not know much about the subtleties of the family life in "traditional" Africa. The reason - a rapid expansion of the European model in the period of colonialism and imperialism. Throughout the continent, the traditional family model became the subject of harsh criticism from Christian churches, humanitarian organisations or governments. Indecent (sexual chaos) or inhumane (towards women or children) elements were sought in it. Basically, this situation has remained unchanged to the present day, and the African family very often fits into a dichotomous structure: tradition versus modernity.

A particularly difficult situation exists in relation to the category of fatherhood. This topic has been largely disregarded in African studies. For anthropologists, in their descriptions and analyzes of kinship systems, children, childhood, adolescence or generally family studies seemed to be more interesting topics (Evans-Pritchard, Forde, Goody, Barth, Fortes, Lewis, Mair and others). As a result, vague theories in the spirit of Marx and Social Darwinism were popular, often not free from the harmful prejudices of "other" "unconventional" social roles held by males in an Africa that was deeply immersed in extremely patriarchal social arrangements. It's enough to mention here the popular-ethnographic works of Dudley Kidd: The Essential Kaffir (1904) or Savage Childhood (1906). Today in turn, in the context of Africa, one can hear about apparent universalism, about "globalized" or "emergent fatherhood" - and a man is placed in a nuclear, monogamous family - and it is there where he should find his social roles or identity (Marshall 2009: 166-201; Inhorn, Chavkin, Navarro 2016: 6; Smith 2016: 315, 322-324). What is interesting, this model is becoming influential even in those parts of Africa where traditionally Islam exists (Inhorn 2012). For some, this is evidence of the masculinity crisis so apparently symptomatic of our times - for others it is an element of social change, as a man navigates and adapts to his changing social worlds. Indeed, fatherhood, as well as masculinity, is undergoing dynamic changes today (if not always); it is being discovered, reinterpreted and agreed. Shortly: it is being adapted to the permanently changing reality. Africa is no exception in this respect. In fact the research on masculinity in Africa has been growing and evolving in recent decades (Lindslay, Miescher 2003; Lahoucine, Morrell 2005; Smith 2017 and many others), the works on fatherhood are rare, especially when referred to particular regions or countries (Read 1960; Nsamenang 1987: 388-413; Richter, Morrell 2006; Smith 2016). If undertaken, they are characterized by a cross culture perspective and culturalism. The research in anthropology has differed from that of other disciplines in showing the variety of ways in which fatherhood is socially constructed and determined, varying considerably around the world. It shows that fatherhood is linked to multiple narratives. It belongs to the people who are in it, but it also belongs to the people who are supporting it and living around it: family, friends, community. In recent years much research 
has been conducted on the fatherhood in the context of "emergent masculinities" - a process of reconfiguration of gender roles and identities that results in new forms of manhood (Inhorm 2012). The article examines social practices with special emphasis put on the changes in men's experience of fatherhood in modern rural Northern Sudan. It appears here that fatherhood is intricately related to a wide variety of practices, customs and narrations, all of which can throw some light on the local model of masculinity and its dynamics. The paper suggests that fatherhood in case of the Muslim community of Northern Sudan can be considered both as a social practice and a theoretical construct. Basically, I recognize the complementarity of these two different perspectives. Fatherhood (just like gender or kinship), on the one hand, is a whole bunch of various social practices: seeing a child to school, playing in the playground, reading at bedtime are all different manifestations of fatherhood that are performative in character (just like gender in terms of Judith Butler) and in many cases also much individualized. These activities are also contextual, variable and inclusive, some disappear, others appear depending on the situation. On the other hand, fatherhood is firmly embedded in the structure - the idea of determining the origin, the division of roles and the responsibilities in the family or the authority relations.

My findings rely on almost twenty years of research in the villages of Northern Sudan on different issues of every-day life. The research was undertaken mainly in two villages: ed Ghaddar and Banganarti, inhabited by an Arab-Nubian population. The majority of the population leads a sedentary, rural life on the very banks of the Nile. They are all Muslims. This is the reality I will most frequently refer to in my article. My knowledge of fatherhood in Africa does not come from systematic research. On the one hand it results from the specific and ethnographic experience subject to reflection, but chaotically gathered - on the other hand it is the outcome of my life situation - the fact of being a father myself. Both these facts equally influenced the preparation of this article.

\section{Being a father in Northern Sudan}

In Northern Sudan the status of a man is neither given nor assigned. To achieve it, it is necessary to persistently keep up climbing the social ladder. This is an effort that practically never ends. Being a man is a matter of becoming - not being. It is a universal thing world-wide - it is not limited to Sudan or Africa at all. Being a man must be reproduced all the time (Lindsay, Miescher 2003). In Northern Sudan, often even an aged man is required to tie the knot when only he is in good health and a stable financial position.

In Northern Sudan manhood is achieved through marriage, but fatherhood as well. This is an unconditional matter. Without it, his status as a man is uncertain. There is a waiting period, as in the case of woman, in which a man tries to make 
his wife pregnant for the first time. If this period is prolonged, he will usually face the ostracism of his family, but above all of other men. One of my friends, unsuccessful, trying to make his wife pregnant, could hear many unpleasant opinions and advice from his fellows. He was offered only two solutions: to divorce or get a second wife. Fortunately for the unfortunate, fatherhood does not always have to be a biological relationship. Fatherhood has not only a biological, but also social and classification dimension, and various relatives, like for example, a mother's brother ( $\mathrm{hal}$ ) can play the role of a father. This is a very important figure, often having greater competences than a biological parent. A proverb says: "An uncle is a father." A man should also have a great affection for his brother's children. In fact, a child may have a father in any male relative who enjoys great authority in the family. "Anyone who is older can be your father," these are the words of one of my interview partners. For one of my friends, his grandfather - a venerable Sufi master - was such a person. Being his favourite, he received the most important life lessons from the grandfather, and not from his biological father. For another of my research partners, such a person was his elder sister who, after the death of his father, took upon herself to raise younger brothers and sisters. Finally, they may be complete strangers, as in the case of the Sufi Brotherhood or a Quranic school, where father-son relations between the master and the pupil are maintained. A similar situation used to exist once in the case of a slave. He was obliged to treat his owner as a father and called him yaaba. In other words, any man can find fulfilment as a father being an uncle, a grandfather, a foster father, a stepfather or just a honourable person. All these categories include a certain measure of this category. It is interesting to realise that a man (maybe to some extent just like a woman through suckling) is able to establish nearly a full kinship relation to any person outside the intimate family.

A particularly important matter for any man is to have a son (photo 1). This is an imperative originating from the patriarchal system of inheritance and relationship existing in a large part of the African communities, including Sudan. For the South Sudanese Nuers or Dinks it is such an important issue that "ghost marriages" are practiced. A man marries a woman only so that a child begot with her could be considered as the dead man's (Evans-Pritchard 1940). Today still very many polygamous marriages have such a genesis. A child is the case here. Death is no explanation. The dead are still members of the kinship group and must have male descendants (Kurcz 2012). A similar situation exists in the case of the Nubians. A person is not a totally autonomous being, exists only in relation to a group, to others. That is why it is expected that children will support their parents in their autumn years. Of course, according to the Muslim tradition, they will also bear their names. Which in turn will make a memory about them survive. It is said: "if you have a son - you will never die" or "a man who has a son will never be forgotten." In Northern Sudan the reproduction of a community is also the case, and 
both in terms of the family and tribal dimension, and faith, which is considered the basic task of any man.

\section{Big man}

Fatherly relations in the first place concern the son, not the daughter. For the greater part of her childhood she will be rather under the care of her mother and not her father. These are the rules of an extremely patriarchal world. In the case of Northern Sudan, they are further strengthened by Islamic law. Two sexes and therefore two worlds. Each is obliged to follow its own path. The crowning achievement of each is a normative model characteristic for men and women. This is how the circle of life closes.

A son is to replace the father as the head of the family. That means he must watch over the honour of its members, women in particular, take care of the farmstead or lead a spiritual life of the family. In other words: a son is prepared for a very important role - this is the role of an "important person". So little and so much. A son of a Sufi master will be a Sufi master and will head the structure managed by his father. He only has to take over some personality traits from him such as: wisdom, responsibility, hieraticism, attachment to tradition, but also an appropriate appearance or the way of life. "My father taught me how to live, how to dress up elegantly," convinced me one of the interview partners. His father was supposed to be extremely generous. He also took this feature over from his father. Another, in turn, would say: "I love my father because he taught me many things a respect to people in the first place. And this is the most important thing in life of any person." Mastering all these attributes, step by step, a son will become father automatically as if. The most important thing for a son is to be able to resemble his father as much as possible. On this basis the son is evaluated. It is often said: "he is as diligent as his father" or "a good son becomes similar to his father in terms of morality." A problem appears if the son does not want or cannot live up to trust placed in him. Disability or a lifestyle that does not fit into the normative model can be such an obstacle. Then the "father's legacy" is not for him, and the relationships with the father become seriously complicated. It is said then: "the father is good, but the son has become bad." Father's expectations are often the reason for an open competition between sons - especially if they have different mothers. That is why the age category is not always the most important aspect for the father. It plays a certain role. The firstborn child, and regardless of gender, should attract the father's special attention. Since it will play an auxiliary role in the upbringing of younger siblings - it must set a good example and it would be best if it could come as close to the father's ideal as possible. The most important are, as it is emphasized, the character traits, with responsibility for others in the forefront. 


\section{A father's role}

The father's role, in the initial period of child's development, is vague. He is a father physically and metaphorically effecting a child from a distance - he is a respected senior, a breadwinner, not taking part in the child's life. He is the master of ceremonies, not of everyday matters. He is the proverbial "first sower." He always has the last word. It is said that his voice should be "the loudest." The prototype here is the concept of God found in the Quran. For example, filial relations are not about establishing a bond with the father, but about obeying his instructions and taking over his attributes. This kind of fatherhood proved well in polygamous families, where the father could not always be present or did not have time for a usually very large number of offspring (Fortes 1950: 252-284; Evan-Pritchard 1965: 45, 46). Just like in the case of a student who, as he was convincing me, practically did not see his father at home. As he had established a new family. Another interview partner, also coming from a polygamous family, confirmed this fact. In his case he meets his father at home only on Fridays. Nowadays also migrations increase the distance from the offspring. A father working far away is an extremely common phenomenon today. A similar model exists in the big number of cultures of the African continent (Fortes 1950: 252-284; Evans-Pritchard 1940: 13-37; Nsamenang 1987). In Northern Sudan most of the household chores are the concern of a woman - and her offspring (Barclay 1964). It is said that "a goat learns to jump with its mother." A man, on the other hand, appears when there is a need to intervene, if there is a problem or an important issue to be resolved. One of such cases, in which he manifests his omnipotence, is the choice of a name. The father chooses a name that relates to honourable ancestors (usually grandfather) or heroes of Islam. It is believed that this will have an impact on the descendant's fate. In this way the father gives the child an identity. A woman is totally passive in this case. As a rule, every child for the first few years, and sometime even throughout the entire life, apart from the official name, also has a name given "unofficially" by its mother. For example, my acquaintance Omar, who is called Dodo by everyone in the neighbourhood, this name was chosen for him by his aunt on his mother's side when he was seven.

Building toys may be an expression of father's involvement. It can be considered one of the manifestations of a new model of fatherhood. Toys are almost only toys for boys, miniature buses, trucks, pickups... In other words, vehicles found on Sudanese "roads." Although a child learns quickly to produce such toys with his own hands, the first prototype car is built for him by his father. For him it will be the most important toy, which he will not part with for many years, treating it with nostalgia. It is worth adding that these toys are rather a new phenomenon. Since earlier no special things were made for children to play with. Children were treated as little adults, not as their opposites. It was thought, therefore, that the youngest did perfectly well themselves in terms of play, and the surround- 
ing world provided ideas for play. Many parents still represent this approach, and their children play with toys constructed by themselves, being miniatures of objects used by adults. This can be a worn tyre or hand-made miniature clay bricks.

A certain change can be observed today also, towards democratisation of parents' roles and duties, but intensification of relations with children too. New technologies turn to be extremely important in this respect. From a photograph being a phone "wallpaper" through regular text messages or conversations (photo 2). That is how the relationships with children are cherished. Paradoxically, the "sowers" of the changes are fathers not staying with their families every day. Digital communication options force the "remote fathers" to re-conceptualise the father's roles and duties and to look for new planes of interaction. One of my Sudanese friends, working for his Ph.D. degree in Poland, communicates with his family via instant messengers. They are audio and video conversations, held regularly every day, often more than once a day. Usually the initiative is the father's. He communicates directly with the child. This is important, he says, because a phone is something private, intimate. Of course, with more emphasis on conversation, telling current stories. A side effect is the departure from "traditional" father's privileges - corporal punishments. "Rhetoric of convincing", "rhetoric of promise", or "rhetoric of frightening" appear in their stead. My friend admitted that his relations with children had become more profound as a result of digital communication.

\section{“Little king”}

The father's duty, but also a form of showing affection, is to organize ceremonies of initiation, such as the naming (simaya), scarification (shilukh) and circumcision (tahur) ceremonies. From the point of view of faith and society, the most important is the latter (Barclay 1964).

According to the Muslim tradition, each boy should be circumcised. Generally, the Sudanese respect this religious custom and attach great importance to it (Trimingham 1965). Circumcision is performed on boys of several years of age generally before starting school. It is always a great holiday. As the proverb says: "An Arab is king on the day of his wedding and circumcision." This day is an important moment for both the circumcised boy and his father, who is renewing his status as a man and the head of the family at the same time. During the ritual, he also obtains real control of his son. On this day the child leaves the company of his mother and sisters, in which he has grown up, and enters the world of men. In a word: he becomes a "little man" and at the same time a fully-fledged follower of Islam. For the boy, this is an important, but at the same time difficult moment. His life changes radically and his relationships with his father begin to germinate. This is a necessary stage from the point of view of the valid model. Every boy has to go through it. 
A life change is illustrated by objects connected with the ceremony. Thanks to them we can see that something ends - and something begins. We are dealing here also with a symbolism of being born again. We also learn that each breakthrough change is marked with a metaphysical danger. That is why a taboo exists and protective measures are necessary. On the day preceding the celebration, the boy is dressed in female attributes. His hands are decorated with henna and kohl (ore of antimony used by local women to dye skin). In this part of the ceremony the boy's masculinity is taken away from him, and he himself is brought to a hermaphroditic condition. An ornamented hilal is put on his head, a bracelet (hereza) on his wrists, and above all a jirtig - a purple knot. These are objects preventing the operation of evil powers, appearing at important, breakthrough moments in human life. On the other hand, on the occasion of circumcision, the boy receives also a typically masculine set, which is of course, purchased in advance by his father. It is a signet ring that the boy will wear for the rest of his life. Above all, however, he receives the first, complete male garment - it consists of a long shirt (araga), a slightly oversized jellabiya, a cap and a pair of leather shoes. All like in the case of an adult man - but only in a miniaturised size. On the eve of the ceremony he is also offered a whip or a sword - symbols of masculinity and at the same time powerful apotropaic items. At some point the boy is also seated on the back of a donkey or a camel on which he is taken around the area to manifest the approaching event.

The ceremony itself takes place in the morning. The surgery is performed at home by a doctor or a local paramedic, specially brought in for this occasion. $\mathrm{He}$ has professional tools and dressings at his disposal. The boy is lying on the bed alone, around the guests and the family are watching everything. He should not cry. The specialist with one skilful movement stretches and cuts off the tip of the foreskin with special scissors. All this is looked at from close up by the boy's father. Then you can hear a happy squeal of women and a loud and exuberant sound of the drum Then the child is carried into a room and laid on the bed. The incense is lit and an iron object is placed under the bed. After a while the guests enter the room; they congratulate the boy and put wads of banknotes in his hands.

A few more days must pass for the boy to be able to fully enjoy the new status. There is a taboo, among other things, that the boy cannot be visited and he cannot leave the farmstead. Finally, on the seventh day there, a solemn procession sets out for the Nile. The boy has his feet, hands and face washed in the river. Then he can also throw a javelin to manifest his masculinity. Just like on the occasion of birthday, "waste" associated with the surgery and gifts for the river creatures in the form of food are thrown into the river. Since that moment on, the boy can leave the farmstead. 


\section{Learning time}

The first years of the boy's life is a carefree period. That is how one of my interview partners recalls it: "when I was little everything looked totally different. My father never punished me; he threatened, but never kept his word, even if I did something bad for the second or third time. I could do anything, and my father spoiled me and showed a lot of affection; I was a little king." Very often I could see severalyear old boys who accompanied their fathers during daily friendly meetings, they were put on fathers' laps, cuddled and fed with sweets. In the area of social life or relaxation, the father and the son are almost inseparable (photo 3). Around the age of seven the period of boy's carefreeness ends. It is considered that a boy starts growing up, and this should result in fundamental changes.

Childhood in Northern Sudan is poorly differentiated - children get used to their future roles since early years. This is not any formalised process. Children learn spontaneously; they take part in certain activities, watching and imitating parents and their surroundings. Probably a universal pedagogical method is compulsory: "watch and learn." The children also quickly become an important element of the family circle, showing, to a certain extent, their economic and productive potential. A son working behind the counter, looking after the grazing animals or taking part in field work - these are situations you can see quite frequently (photo 4). Every evening the father has a habit of talking with a son about works done and those to be done the next day. It makes you think of a Quranic school where every evening a student is asked about the material he has learned during the day and then is given a new part of Quran by the teacher to master.

It is worth noting that the traditional educational system is not only limited to the family, but also includes the tribe, the social and age group (Barclay 1964). In a word: everybody. The voice of the father is the loudest, but the symbols of fatherly authority can embody many people: friends, relatives or public figures, including women. In Northern Sudan, like in many areas of Africa, we may talk about the "extended parenthood" (Evans-Pritchard 1965). Everybody takes part in the process of socialisation of an individual (Barclay 1964). That is why, among other things, an old tradition of giving children away to be educated by a distinguished patron is practiced here. Often, they are religious sheiks under the banner of Sufism who are involved in running traditional Quranic schools (Trimingham 1965: 117). The Quran and Arabic are taught in them, as well as the arcane knowledge of folk religiousness. Tuition is free, but boys have to provide all sorts of services for their master, most frequently serve at his home or work in the field. Not only education does have to be the reason. One of my interview partners convinced me that he always sent his son to his wife's brother for holidays, that is a relative as I have mentioned, who, in the family, holds a position close to that of a biological father. He lives in distant Butana. These trips are, in the first place, to cherish for family relationships. 
A son is obliged to obey his father, the father to provide him with advice. Actually, this situation never changes - even if the son heads his own family, he will have to consider his father's opinion. Among Ja'aliyyin Arabs - the genealogical descent from whom is admitted by a large part of the Nile valley inhabitants - the symbol of fatherly authority is a whip made of camel tail - present in many houses and transferred often from generation to generation. The father has the right to use it in the event of insubordination of his charges. Nothing, however, indicates this right is abused. One of the interview partners admitted that he had received a hiding from his father (with a belt) only once in his lifetime. Another denied such a situation had ever happened at all. Personally, I have never witnessed such an event.

"Good parents have good children" or "ash is born from flames." A good father, above all, should be an authority for the child and set an example for him. And a child acquires the necessary knowledge through the participation in everyday matters. A rule is applicable: "watch and learn." That is why quite frequently you can see a father and his several year-old son at a market, shopping or looking after the grazing animals together. As time goes by, the little boy starts staying with other men more and more frequently. He is allowed to serve at the table and participate in shared men's meals (photo 5). He is taught how to behave in the company. Finally, the father begins to take his son to religious ceremonies: to an ecstatic dhikr or to Friday prayers. The father plays a fundamental role in preparing a son to the role of being a good Muslim. This is one of the father's priorities as regards his son's education. "My father prayed with me every day and finally started taking me to the mosque with himself."

Around the age of seven, the boy's attire changes. Children's clothes of a truly European style are replaced by a typically masculine, but also a much more traditional fashion; a white long shirt with a zucchetto or turban on the head. The accelerator of these changes is, as I have written, circumcision. A category of space is important in this respect. The family home, but also the households of other traditionally close relatives, a nearby street, a mosque, a market, are all spaces in which the child acquires certain values. One of my interlocutors mentioned that the place where his character was forged was a zauja belonging to his relatives. $\mathrm{He}$ came across the entire spectrum of examples of human behaviour there. Witnessing with his own eyes, he could become convinced what generosity, helpfulness, respect, love, hieraticism or piety mean. One father, in turn, emphasised the importance of a weekly meeting at the grandfather's house in education sons. Every Friday the male part of the family was to pray together at a mosque, and then dine at the family home. My interview partner took part in this family "ritual" only with his sons. That's generally the reason why fatherhood is very often connected with mobility. It is a man's privilege and the way of life. Fatherly practices are shorter or longer excursions - evening visits at relatives', but also doing shopping together on a market or visits to a mosque. 
In the initial period a lot of attention is paid to discipline ( $a d d a b)$. It is understood as respect for the elder expressed through a range of different practices, many of which are corporal in nature. When and whom the child should be ready to help. To whom and how to speak. Who should be served a bowl of broad beans and who a piece of meat. It is important that the child learns a proper behaviour in relation to different spaces and people (for instance to which houses a child may walk into unannounced or what obligations to the certain group of relatives are). Teaching that sort of skills is primarily the responsibility of the child's father. The father motivates the child, usually using the rhetoric of threats and rewards, frightening and flattering, punishing and rewarding.

A son addresses his farther rather formally "father", always with a quiet voice and not raising his eyes. He should not sit on one bed or sofa with him either. In turn, when guests come, he should always be ready to help and will rather not take part in discussions. Generally, he is obliged to meet his father's expectations halfway: prepare water for ablutions or bring breakfast to work. This is the desideratum of ideal son's practices. With time, some distance appears between the father and a son. It is a manifestation of respect: son's respect for his father, but also of a confirmation that the son is becoming an adult person, a fully-fledged member of the male community. The father, apart from the already rementioned "ceremonial" prerogatives, gives his son more and more freedom, both in terms of social and professional life. All this is to help a boy in forming his character.

Responsibility is another character trait which, as a rule, the father has the duty to form. Many of my interview partners mentioned it. The child acquires this ability by participating and imitating the father in such activities as: taking care of animals or younger siblings, shopping. The proof of recognition in the eyes of the father - in a way also of fatherly love - lets the son have more and more independence. Initially, it may be giving him a donkey. This is simply a common practice in Northern Sudanese rural areas. On its back he will be able to travel to school, for example. With time, without any doubt, a mobile phone will become such a tangible sign of fatherly love, so the son could should finally get a permit to earn a living. Money obtained this way will be his - although, as in case of the son of my friend, it is frequently voluntarily given to the father in the name of filial responsibility for the family. Finally, certain objects, which are symbols of authority or masculinity may be the manifestation of fatherly love. A saddle, a sword or a ceremonial stick are the most frequent ones among former nomads.

\section{Marriage}

The crowning achievement of man's attempts to educate a son is the arrangement of the most important ceremony - marriage. God gives the father the right to arrange marriage of his children according to his own desires and interests. 
The arrangement of marriage is therefore a natural element of fatherly authority. It is also a measurable form of showing fatherly love. Marriage, however, is also a fundamental stage on the way to a young person's independence. Like in the case of other crucial ceremonies, the father's contribution has a formal character, and the entire effort of the complicated marital negotiations falls on the shoulders of women. Fathers usually join the matter at the very end, when everything has been somehow buttoned up and there is no danger of losing face. Arranging marriages is still an obvious mission. Since marriage is an agreement between two families, not two people. It is a duty in relation to the family, not to one's own heart. After all, it is about a new social relationship, strengthening of the family, acquiring brothers-in-law or marrying into a good kinfolk - simply, very serious matters.

\section{Conclusion}

The discussion about fathers and fatherhood in modern Northern Sudanese society has indicated certain major patterns. Fatherhood is neither a stable or homogenous concept. There is a wide variety of father's ways: providing father, Godfather, spiritual-father, uncle-father, digital father, distance father, femme-father etc. Fatherhood should be considered both as a social construct and a bench of social practices which are very individual, inclusive and performative in character. Although fatherhood can have a social and classification dimension, it is still a particularly important matter for any man to have a biological offspring - a son in particular. It is matter of community reproduction, but also enjoying a full status of man. When a son takes over the roles of a father it is widely recognized as the most desirable and is seen as a proof of the man's high status. It has been noted, however, that this process is not always easy to carry out today. Because of son's education or his economic activity, he becomes more and more independent afterwards. This matter is particularly important when a father is far away from home. What is interesting here, the father-son relationship often becomes reinforced or re-established, especially by means of new communication technologies. To put it briefly: the role of the father has undergone noticeable changes in recent years. Probably they have been a result of migrations or modifications in the village economy. These changes, however, need further ethnographic investigations. Finally, paternity is associated with gender, with social roles attributed to a man or a woman. Being committed and responsible father often means nowadays the breaking of the normative model. Greater involvement in the raising of children is treated as weakening of masculinity, or even leading to the demasculinization of a man, lowering his social status and destabilizing the ontological concept of masculinity. That is generally the reason why the new ways of doing fatherhood are nowadays so problematic and not easy to follow at the same time. 


\section{Bibliography}

Barclay H.B.

1964 Buurri Al Lamaab: A Suburban Village in the Sudan, Ithaca-New York.

Evans-Pritchard E.E.

1940 The Nuer: A Description of Modes of Livelihood and Political Institutions of a Nilotic People, Oxford.

1965 The Position of Women in Primitive Societies and Other Essays in Social Anthropology, London.

Fortes M.

1950 Kinship and Marriage among the Ashanti in: A.R. Radcliffe-Brown, B. Frank (eds), African Systems of Kinship and Marriage, Oxford.

Inhorn M.C.

2012 The New Arab Man: Emergent Masculinities, Technologies and Islam, Princeton. Inhorn M.C., Chavkin W., Navarro J.-A.

2016 Globalized Fatherhood: Emergent Forms and Possibilities in the New Millennium in: M.C. Inhorn, W. Chavkin, J.-A. Navarro (eds.), Globalized Fatherhood, New YorkOxford, p. 1-31.

Kurcz M.

2012 Jak przeżyć w afrykańskim mieście?, Katowice.

Lahoucine O., Morrell R. (eds)

2005 African Masculinities, New York.

Lahoucine O. (ed.)

2006 Islamic Masculinities, London-New York.

Lindsay L., Miescher S. (eds)

2003 Men and Masculinities in Modern Africa, Portsmouth.

Marshall R.

2009 Political Spirituality: The Pentecostal Revolution in Nigeria, Chicago.

Nsamenang A.B.

1987 Fatherhood: A West African Perspective in: M.E. Lamb (ed.), The Father's Role:

Cross-cultural Perspectives, Hillsdale, NJ, p. 273-293.

Read M.

1960 Children of the Fathers: Growing up among the Ngoni of Nyasaland, New Haven.

Richter L., Morrell R.

2006 Baba: Men and Fatherhood in South Africa, Cape Town. Smith D.J.

2016 Fatherhood, Companionate, Marriage, and the Contradictions of Masculinity in Nigeria in: M.C. Inhorn, W. Chavkin, J.-A. Navarro (eds.), Globalized Fatherhood, New York-Oxford, p. 315-359.

2017 To be a Man is not a One-Day Job: Masculinity, Money, and Intimacy in Nigeria, Chicago.

Trimingham J.S.

1965 Islam in the Sudan, New York. 


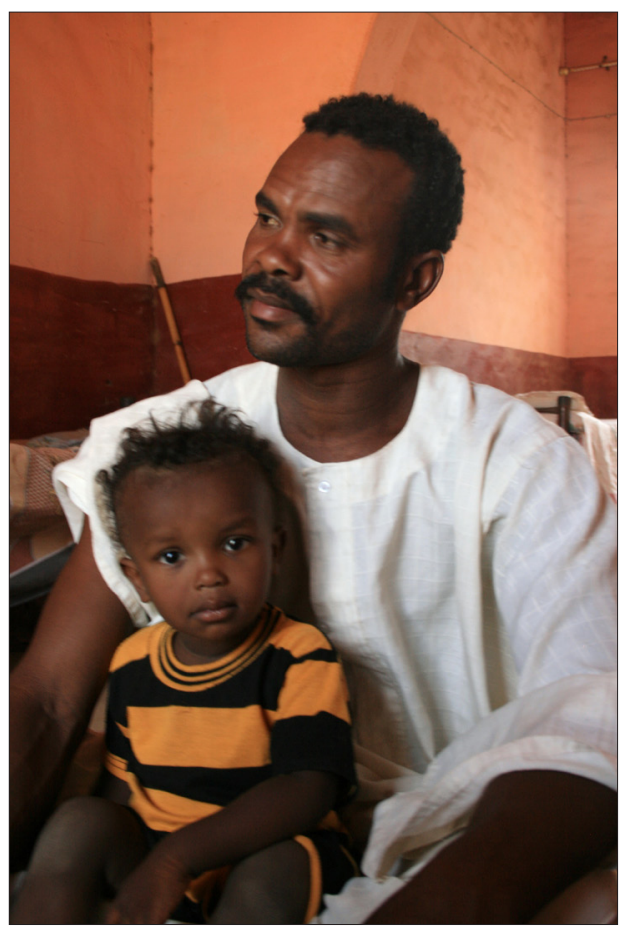

Fot. 1. Ojciec i syn, Hammur. M. Kurcz 2013

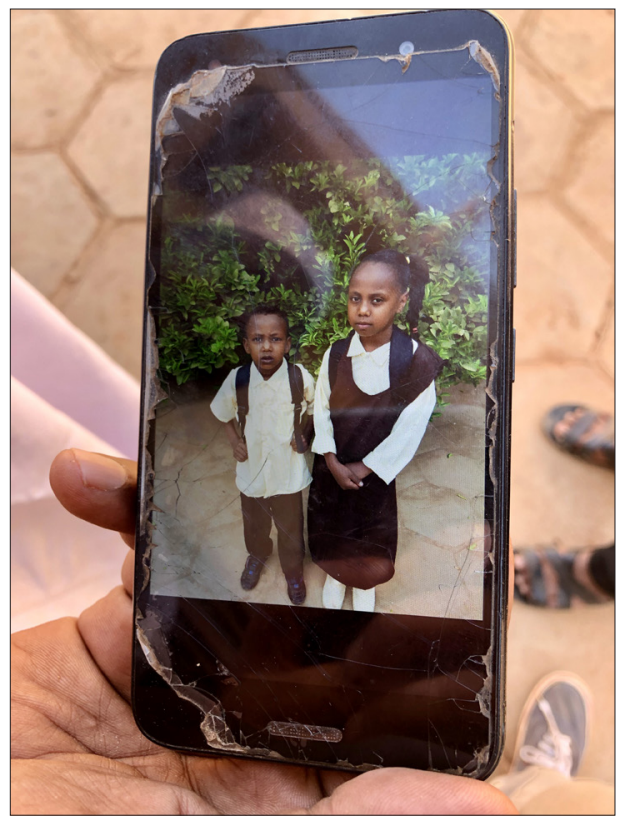

Fot. 2. Tapeta telefonu Ahmeda, Soba. M. Kurcz 2019 


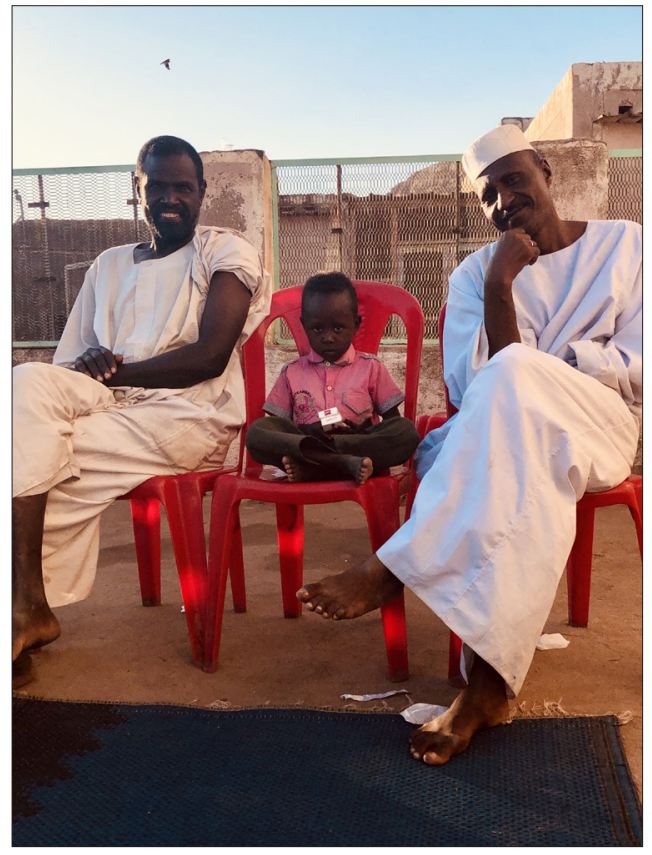

Fot. 3. W męskim gronie, Jebel Moya. M. Kurcz 2019

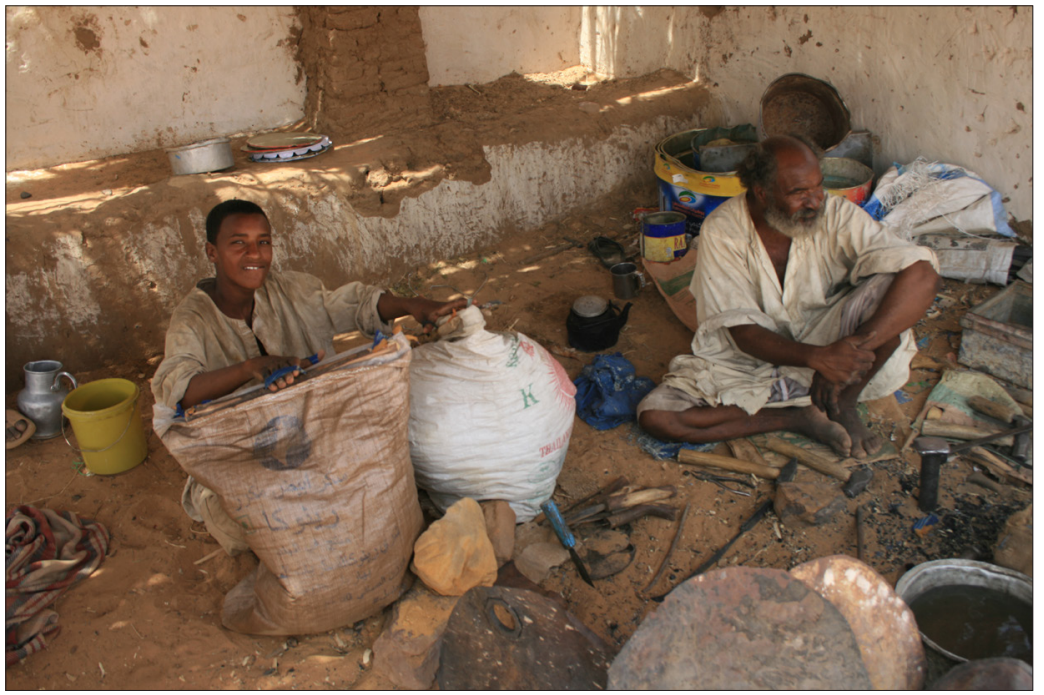

Fot. 4. Kowal Jozef wraz z synem, Hammur. M. Kurcz 2013 


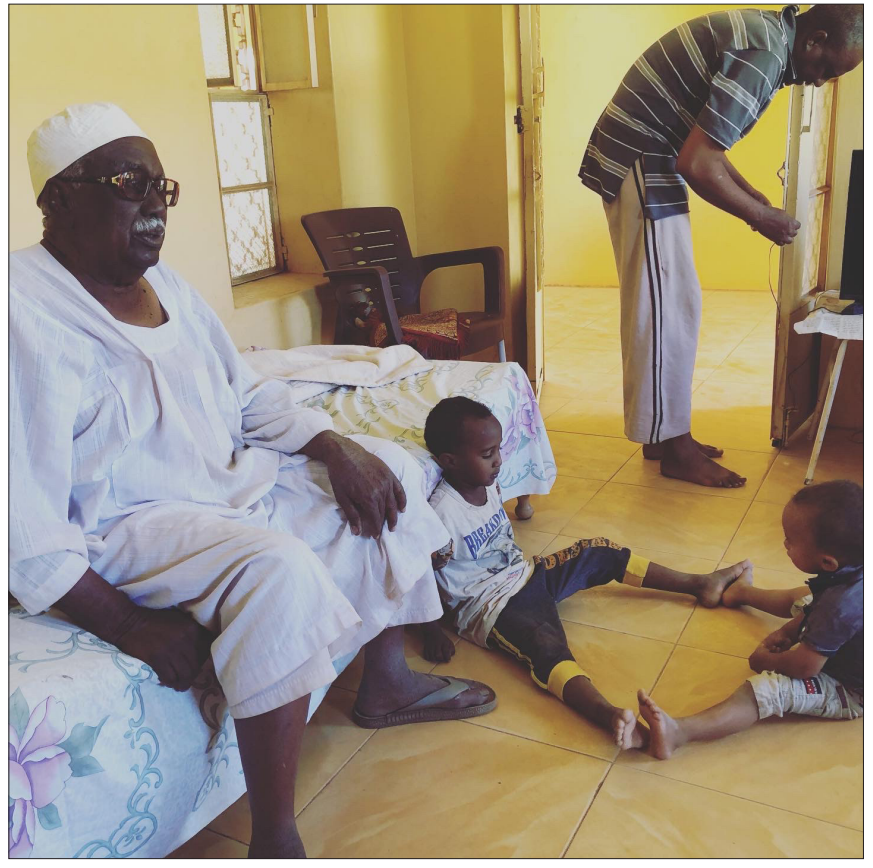

Fot. 5. Trzy pokolenia mężczyzn, Soba. M. Kurcz 2019 